\title{
HULL RESISTANCE OF AN INLAND WATERWAY VESSEL IN MODEL SCALE AND IN FULL SCALE
}

\author{
Tomasz Tabaczek \\ Maciej Zawiślak \\ Wrocław University of Technology, Poland
}

\begin{abstract}
Data from model tests of an inland waterway vessel in shallow water have been used by the authors to prepare the resistance prediction in full scale. The common ITTC-1978 extrapolation procedure was applied using form factor determined according to the Prohaska method and, separately, by fitting the approximation function to resistance data. At the same time a series of CFD computations of ship flow has been carried out in model scale and in full scale, with double-body model as well as including the effect of free surface. The results of computations were used to determine total resistance and form factor. The values of form factor determined using different methods are similar and relatively high in comparison to values being applied to conventional sea going ships. Resistance prediction according to the ITTC-1978 with form factor was compared to prediction without form factor. The relative difference of resistance amounts $28 \%$ at ship speed of $10 \mathrm{~km} / \mathrm{h}$ and $24 \%$ at ship speed of $12 \mathrm{~km} / \mathrm{h}$.
\end{abstract}

Keywords: inland waterway vessel, ship resistance, form factor

\section{INTRODUCTION}

Prediction of resistance of inland waterway vessels, especially of innovative hull form, is made usually with application of model tests and extrapolation of measured resistance. The International Towing Tank Conference (ITTC) recommends the procedures both for tests [1] and extrapolation [2]. The recommended method of extrapolation is the form factor method with form factor determined according to the concept proposed by Prohaska [3].

When re-analysing model test data for an inland motor cargo vessel designed for operation on the Oder River [4] the authors encountered the relatively high value of form factor. Hull form of that twin-screw vessel is distinctive by bow form with wide- $\mathrm{V}$ cross sections, propeller tunnels and stern transom (see Fig.1). The breadth to draught ratio (B/T) of 5.2 is typical for inland waterway vessels operating in shallow inland waterways.

The authors decided to verify, using CFD, the form facto determined according to the Prohaska method. Computations of ship flow have been performed for model ship as well as for full scale vessel, both for double-body model. Form factor has been determined as ratio of total hull resistance to the frictional resistance determined according to the ITTC-1957 model ship correlation line, as suggested in [5].

Because of the high value of form factor the resistance at service speeds predicted using the form factor is lower by about $25 \%$ from the resistance 

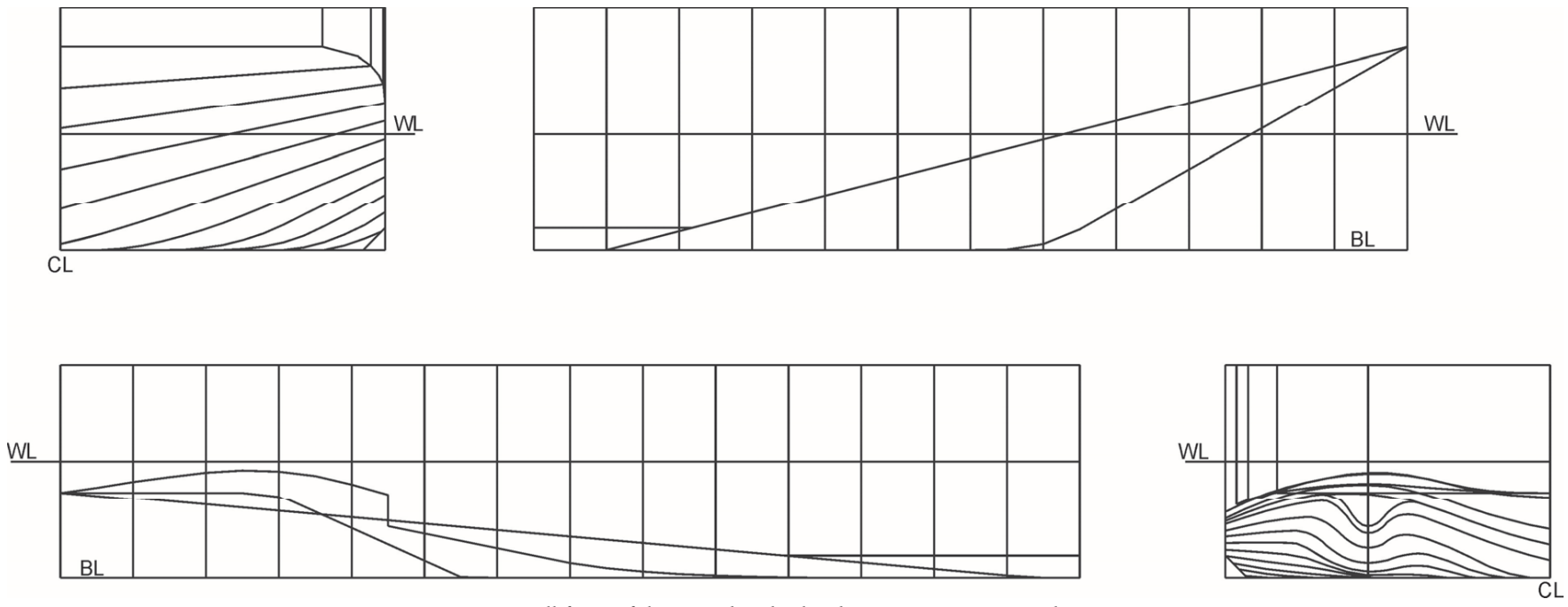

Fig.1. Hull form of the considered inland waterway cargo vessel OBM

predicted according to the original Froude method $(\mathrm{k}=0)$.

\section{INLAND WATERWAY VESSEL OBM}

The considered inland motor cargo vessel (referred to as OBM) was originally designed in Inland Navigation Research and Design Centre - Navicentrum in Wrocław, in 1973 year. Main dimensions were fitted to the parameters of the Oder Waterway of that time. The vessel was designed to operate at draught of $1.60 \mathrm{~m}$ (optionally at draught of $2.36 \mathrm{~m}$ ), either alone $\left(\mathrm{L}_{\mathrm{OA}}=70 \mathrm{~m}\right)$ or coupled with a single dumb barge $\left(\mathrm{L}_{\mathrm{OA}} \approx 116 \mathrm{~m}\right)$. Hull form of OBM is presented in Fig.1, and main particulars are given in Table 1 .

Table 1. Main particulars of the inland waterway cargo vessel OBM

\begin{tabular}{|c|c|}
\hline Length over all, $\mathrm{L}_{\mathrm{OA}}$ & $70.00 \mathrm{~m}$ \\
\hline Length at waterline, $\mathrm{L}_{\mathrm{WL}}$ & $67.83 \mathrm{~m}$ \\
\hline Breadth, $\mathrm{B}$ & $8.92 \mathrm{~m}$ \\
\hline Draught, $\mathrm{T}$ & $1.60 \mathrm{~m}$ \\
\hline Wetted surface area, $\mathrm{S}$ & $773.1 \mathrm{~m}^{2}$ \\
\hline Displacement volume, $\nabla$ & $848.2 \mathrm{~m}^{3}$ \\
\hline
\end{tabular}

\section{MODEL TESTS}

Extensive resistance and propulsion model tests of OBM were carried out in Ship Design and Research Centre in Gdańsk [4]. For the purpose of analysis presented in this paper used were the results of resistance tests in deep water and in shallow water at water depth $\mathrm{h}=2.50 \mathrm{~m}(\mathrm{~h} / \mathrm{T}=1.56)$. Tests in shallow water were carried out in auxiliary towing $\operatorname{tank}(60 \mathrm{~m} \times 7 \mathrm{~m})$ with adjustable depth of water. At the scale of 1:16 water depth was equal $0.156 \mathrm{~m}$.

\section{CFD COMPUTATIONS}

CFD computations of ship flow have been performed for the following conditions:

a. in model scale (1:16) for double-body configuration, in order to determine total hull resistance $\left(\mathrm{R}_{\mathrm{TM}}\right)$ without the effect of free surface (no wave resistance) and to determine the form factor in model scale $\left(1+\mathrm{k}=\mathrm{C}_{\mathrm{TM}} /\right.$ $\left.\mathrm{C}_{\mathrm{FOM}},[5]\right)$;

b. in model scale (1:16), including the effect of free surface, in order to validate the applied CFD method;

c. in full (ship) scale for double-body configuration, in order to determine the form factor in full scale.

The resistance in free surface flow in model scale (b) was in satisfactory agreement with the resistance measured in model tests (Fig.2). The authors recognised the applied CFD methodology as reliable to draw conclusions from analysis of results.

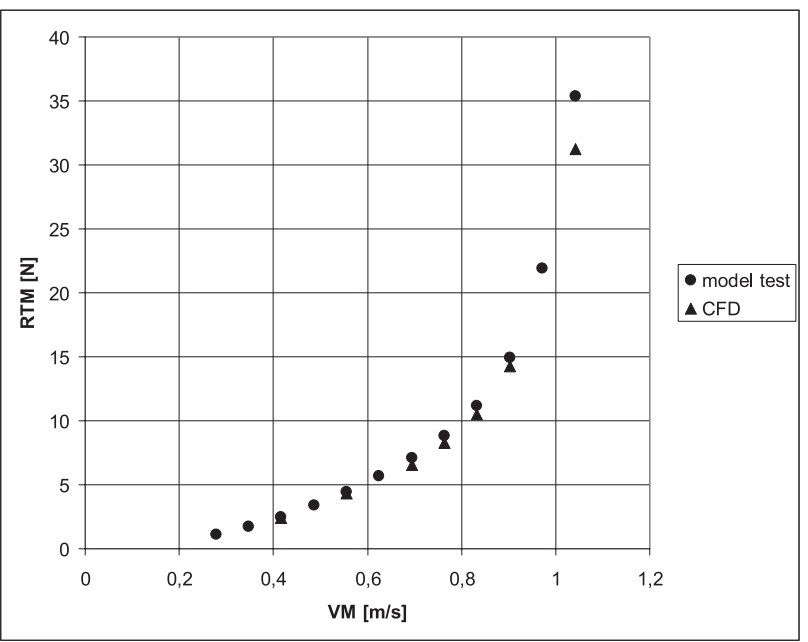

Fig.2. Model ship resistance of OBM in shallow water, $h / T=1.56$ 


\section{FORM FACTOR}

The value of form factor $\mathrm{k}$ for OBM in shallow water has been determined using 3 methods:

- the method proposed by Prohaska [3] and recommended by ITTC [2],

- fitting the approximation function to test data,

- computation of hull resistance with CFD software.

\section{The Prohaska method}

Om the assumption that at small speed $(0.10<\mathrm{Fr}<0.20)$ the coefficient of wave resistance is proportional to Froude number in 4 th power and can be represented as $C_{w}=a^{4} r^{4}$ :

and

$$
\mathrm{C}_{\mathrm{TM}}=(1+\mathrm{k}) \mathrm{C}_{\mathrm{F} 0 \mathrm{M}}+\mathrm{aFr}^{4}
$$

$$
\mathrm{C}_{\mathrm{TM}} / \mathrm{C}_{\mathrm{F} 0 \mathrm{M}}=(1+\mathrm{k})+\mathrm{aFr}^{4} / \mathrm{C}_{\mathrm{F} 0 \mathrm{M}}
$$

The ratio $\mathrm{C}_{\mathrm{TM}} / \mathrm{C}_{\mathrm{FoM}}$ is a linear function of $\mathrm{Fr}^{4} / \mathrm{C}_{\mathrm{FoM}}$. After presenting the data from resistance test in coordinates $\mathrm{C}_{\mathrm{TM}} /$ $\mathrm{C}_{\mathrm{FOM}}$ vs. $\mathrm{Fr}^{4} / \mathrm{C}_{\mathrm{FOM}}$ and fitting them with straight line, the line intercepts the ordinate axis at $1+\mathrm{k}$ [3]. The application of the Prohaska method to determination of form factor of OBM is illustrated in Fig.3.

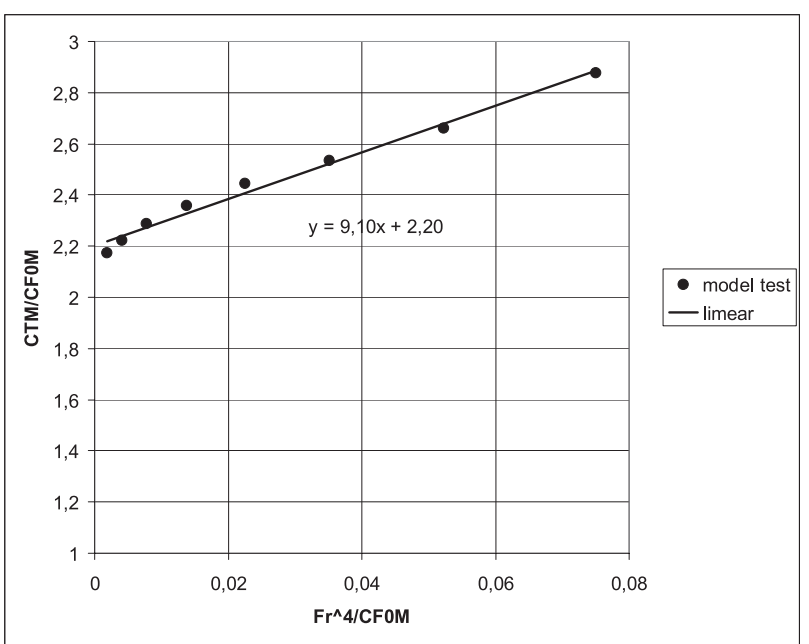

Fig.3. Determination of form factor of OBM at $h=2.50 \mathrm{~m}$ according to Prohaska method [3]

\section{Fitting the approximation function}

Without the requirement of no flow separation imposed by Prohaska, the relationship between resistance and speed of vessel can be approximated using the following function:

$$
\mathrm{C}_{\mathrm{TM}}=(1+\mathrm{k}) \mathrm{C}_{\mathrm{F} 0 \mathrm{M}}+\mathrm{aFr}_{\mathrm{h}}{ }^{\mathrm{b}} .
$$

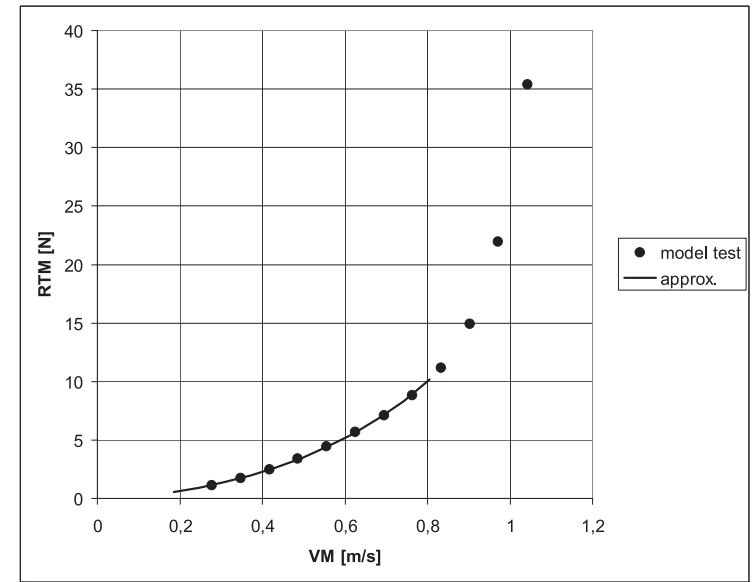

Fig.4. Resistance test data approximated with function $R_{T M}=0.5 \rho V_{M}{ }^{2} S_{M}$ $\left[(1+1.134) C_{F O M}+0.907 \mathrm{Fr}^{2.847}\right] ; O B M, h / T=1.56$

The authors fitted the above function to resistance test data using the statistics software and least-square method. Only data below Frh $=0.65$, i.e. the hydrodynamic ally economic speed limit for small and medium size motor cargo vessels [6], were used for determination of form factor $\mathrm{k}$, coefficient $a$ and exponent $b$. The fit of approximation is shown in Fig.4.

\section{CFD}

Form factor can be computed from the resistance of double-body model computed using CFD:

$$
1+\mathrm{k}=\mathrm{C}_{\mathrm{T}} / \mathrm{C}_{\mathrm{F} 0}
$$

where $\mathrm{C}_{\mathrm{T}}$ is hull resistance coefficient and $\mathrm{C}_{\mathrm{F} 0}$ is frictional resistance coefficient calculated according to the ITTC-1957 model-ship correlation line [5].

Values of form factor calculated for OBM in model scale and in full scale are given in Tables. 2 and 3.

Table 2. Values of form factor for OBM calculated using results of CFD computations in model scale

\begin{tabular}{|c|c|c|c|c|c|}
\hline $\begin{array}{c}\mathrm{V}_{\mathrm{S}} \\
{[\mathrm{km} / \mathrm{h}]}\end{array}$ & $\begin{array}{c}\mathrm{V}_{\mathrm{M}} \\
{[\mathrm{m} / \mathrm{s}]}\end{array}$ & $\mathrm{Fr}$ & $\mathrm{C}_{\mathrm{TM}}$ & $\mathrm{C}_{\mathrm{FOM}}$ & $1+\mathrm{k}$ \\
\hline 5.00 & 0.347 & 0.054 & $9.18 \mathrm{E}-03$ & $4.43 \mathrm{E}-03$ & 2.08 \\
\hline 7.00 & 0.486 & 0.075 & $8.78 \mathrm{E}-03$ & $4.13 \mathrm{E}-03$ & 2.13 \\
\hline 9.00 & 0.625 & 0.097 & $8.49 \mathrm{E}-03$ & $3.92 \mathrm{E}-03$ & 2.17 \\
\hline
\end{tabular}

Table 3. Values of form factor for OBM calculated using results of CFD computations in full scale

\begin{tabular}{|c|c|c|c|c|c|}
\hline $\begin{array}{c}\mathrm{V}_{\mathrm{S}} \\
{[\mathrm{km} / \mathrm{h}]}\end{array}$ & $\begin{array}{c}\mathrm{V}_{\mathrm{S}} \\
{[\mathrm{m} / \mathrm{s}]}\end{array}$ & $\mathrm{Fr}$ & $\mathrm{C}_{\mathrm{TS}}$ & $\mathrm{C}_{\mathrm{FoS}}$ & $1+\mathrm{k}$ \\
\hline 2.00 & 0.556 & 0.022 & $5.30 \mathrm{E}-03$ & $2.46 \mathrm{E}-03$ & 2.16 \\
\hline 4.00 & 1.111 & 0.043 & $4.95 \mathrm{E}-03$ & $2.21 \mathrm{E}-03$ & 2.24 \\
\hline 6.00 & 1.667 & 0.065 & $4.76 \mathrm{E}-03$ & $2.08 \mathrm{E}-03$ & 2.29 \\
\hline 8.00 & 2.222 & 0.086 & $4.65 \mathrm{E}-03$ & $2.00 \mathrm{E}-03$ & 2.33 \\
\hline 10.00 & 2.778 & 0.108 & $4.57 \mathrm{E}-03$ & $1.94 \mathrm{E}-03$ & 2.36 \\
\hline
\end{tabular}




\section{COMPARISON OF FORM FACTOR VALUES}

Table 4. Values of form factor for inland cargo vessel OBM in shallow water $(h / T=1.56)$

\begin{tabular}{|l|l|c|c|}
\hline Source of data & \multicolumn{1}{|c|}{ Method } & Range of speed & $1+\mathrm{k}$ \\
\hline model test & by Prohaska & $\begin{array}{c}0.054<\mathrm{Fr}<0.118 \\
0.28<\mathrm{Fr}_{\mathrm{h}}<0.62\end{array}$ & 2.20 \\
\hline model test & $\begin{array}{l}\text { fitting the } \\
\text { approximation } \\
\text { function }\end{array}$ & $\begin{array}{c}0.054<\mathrm{Fr}<0.118 \\
0.28<\mathrm{Fr}_{\mathrm{h}}<0.62\end{array}$ & 2.13 \\
\hline CFD in model & $1+\mathrm{k}=\mathrm{C}_{\mathrm{TM}} /$ & $\begin{array}{c}0.054<\mathrm{Fr}<0.097 \\
0.28<\mathrm{Fr}_{\mathrm{h}}<0.50\end{array}$ & $2.08-2.17$ \\
scale & $\mathrm{C}_{\mathrm{FoM}}$ & & $0.022<\mathrm{Fr}<0.108$ \\
\hline CFD in full & $1+\mathrm{k}=\mathrm{C}_{\mathrm{TS}} / \mathrm{C}_{\mathrm{FOS}}$ & $0.11<\mathrm{Fr}_{\mathrm{h}}<0.56$ & $2.16-2.36$ \\
\hline scale & &
\end{tabular}

\section{RESISTANCE PREDICTION}

Ship resistance of OBM in shallow water was predicted according to:

(1) the original Froude method, without form factor

$$
\begin{gathered}
\mathrm{C}_{\mathrm{TS}}=\mathrm{C}_{\mathrm{TM}}+\mathrm{C}_{\mathrm{FOS}}-\mathrm{C}_{\mathrm{FOM}} \\
\mathrm{R}_{\mathrm{TS}}=\mathrm{C}_{\mathrm{TS}} 0.5 \rho \mathrm{V}^{2} \mathrm{~S}
\end{gathered}
$$

(2) the form factor method, recommended by ITTC [2]:

$$
\begin{gathered}
\mathrm{C}_{\mathrm{TS}}=\mathrm{C}_{\mathrm{TM}}+(1+\mathrm{k})\left(\mathrm{C}_{\mathrm{F} 0 \mathrm{~S}}-\mathrm{C}_{\mathrm{F} 0 \mathrm{M}}\right) \\
\mathrm{R}_{\mathrm{TS}}=\mathrm{C}_{\mathrm{TS}} 0.5 \rho \mathrm{V}^{2} \mathrm{~S}
\end{gathered}
$$

where:

$\mathrm{C}_{\mathrm{FOS}}, \mathrm{C}_{\mathrm{FOM}}$-coefficient of frictional resistance calculated according to the ITTC-1957 model-ship correlation line:

$$
\begin{gathered}
\mathrm{C}_{\mathrm{F} 0}=0.075 /(\log \operatorname{Re}-2)^{2} \\
\mathrm{Re}=\mathrm{VL}_{\mathrm{WL}} / v
\end{gathered}
$$

Predicted ship resistance is shown in Fig. 5

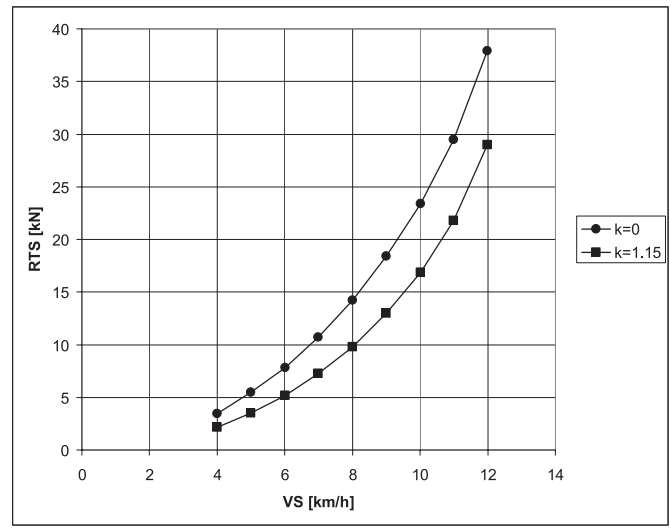

Fig.5. Predicted ship resistance of the motor cargo vessel OBM in shallow water $(h / T=1.56)$
Relative differences between resistance predicted using methods (1) and (2) is $28 \%$ at VS $=10 \mathrm{~km} / \mathrm{h}$ through $24 \%$ at $\mathrm{VS}=12 \mathrm{~km} / \mathrm{h}$

\section{CONCLUSIONS}

Three methods were applied to determine the form factor for inland waterway cargo vessel:

- $\quad$ the common method proposed by Prohaska [3] and recommended by ITTC [2],

- fitting the approximation function to test data,

- calculation of form factor using results of CFD computations of ship flow.

The determined values of form factor are similar, and are relatively high. At water depth of $2.50 \mathrm{~m}(\mathrm{~h} / \mathrm{T}=1.56)$ the form factor amounts around $1.15(1+\mathrm{k} \approx 2.15)$. In opinion of the present authors, such high value is, on one hand, due to wide-beam hulls of $\mathrm{B} / \mathrm{T}=5.2$, with bow form of wide $\mathrm{V}$-shaped cross sections (form factor determined for the same vessel in deep water amounts 0.33 ). On the other hand it is the effect of shallow water.

The comparison of resistance predicted without form factor and with form factor reveals that relative difference in predictions may amount up to $28 \%$ at ship speed of $10 \mathrm{~km} / \mathrm{h}$ (speed limit usually imposed by waterway authorities for navigation in canals) and up to $24 \%$ at ship speed of $12 \mathrm{~km} / \mathrm{h}$ (at $\mathrm{Fr}_{\mathrm{h}}=0.67$, i.e. around the hydrodynamically economic speed limit).

\section{REFERENCES}

4. ITTC-Recommended Procedures and Guidelines, Resistance Test, 7.5-02-02-01, Rev.03, Effective Date 2011

5. ITTC-Recommended Procedures and Guidelines, 1978 ITTC Performance Prediction Method, 7.5-02-03-01.4, Rev.03, Effective Date 2014

6. Prohaska C.W.: A simple method for evaluation of form factor and the low speed wave resistance, Proc. 11th ITTC, 1966, pp.65-66

7. Sprawozdanie z prób modelowych oporowo-napędowych odrzańskiej barki motorowej (Report from resistance and propulsion model tests of the Oder motor barge), RB-NM20/B430-13, Ośrodek Hydromechaniki Okrętu, Centrum Techniki Okrętowej, Gdańsk, 1975

8. ITTC-Recommended Procedures and Guidelines, Practical Guidelines for Ship Resistance CFD, 7.5-03-02-04, Revision 00, Effective Date 2014

9. Heuser H., Müller E.: Verdrängungsschiffe auf flachem Wasser - Neuere Ergebnisse hydrodynamischer Forschung und ihre Anwendung beim Entwurf, Schiffstechnik, Band 33, Heft 1, April 1986 


\section{CONTACT WITH THE AUTHORS}

Maciej Zawiślak

e-mail:maciej.zawislak@pwr.wroc.pl

Wrocław University of Technology

5 Łukasiewicza st.

50-371 Wrocław

Poland 